J. Clin. Chem. Clin. Biochem.

Vol. 15,1977 , pp. 537-560

\title{
Determination of Copper and Iron in Human Blood Serum by Energy Dispersive X-Ray Analysis
}

\author{
By J. Knoth, H. Schwenke, R. Marten and J. Glauer \\ Gesellschaft für Kernenergieverwertung in Schiffbau und Schiffahrt mbH., Institut für Physik, Geesthacht-Tesperhude \\ Federal Republic of Germany
}

(Received January 31/May 4, 1977)

Summary: Human blood serum has been analyzed by X-ray fluorescence spectroscopy utilizing the effect of background reduction by total reflexion of the incident X-ray beam on an optical flat as sample support. For sample preparation a drop of $10 \mu \mathrm{l}$ serum was pipetted onto the support and dried to a thin film. The minimum detectable limit was about $1.5 \mathrm{mmol} / \mathrm{l}$ in $1000 \mathrm{~s}$ and the precision in the $20 \mathrm{mmol} / \mathrm{l}$ range of the metals was $3-5 \%$.

\section{Bestimmung von Kupfer und Eisen in humanem Blutserum durch energiedispersive Röntgenfluoreszenzanalyse}

Zusammenfassung: Der Metallgehalt in humanem Blutserum wurde mittels energiedispersiver Röntgenfluoreszenzanalyse bestimmt, wobei zur Verminderung des Untergrundes der Effekt der Totalreflexion der anregenden Röntgenstrahlung an einem hochebenen Probenträger aus Quarzglas ausgenutzt wurde. Zur Probenherstellung wurde ein Tropfen von $10 \mu \mathrm{l}$ Serum auf den Probenträger pipettiert und zu einem dünnen Film getrocknet. Die Nachweisgrenze lag unter $1,5 \mathrm{mmol} / \mathrm{l}$ in $1000 \mathrm{~s}$ und die Reproduzierbarkeit bei einem mittleren Metallgehalt von etwa $20 \mathrm{mmol} / \mathrm{l}$ betrug 3-5\%.

\section{Introduction}

The determination of iron and copper in human blood serum is an increasingly important tool for the diagnosis of certain cancers and hepatic and metabolic disorders. For this determination standardized techniques have been developed which are routinely used in the medical laboratories. The present paper describes a new method that requires no pre-treatment such as deproteinization, is element-specific and allows the measurement of several elements simultaneously. The technique may therefore become a valuable supplement in medical laboratory practice.

\section{Experimental}

The measuring equipment was a preliminary experimental setup very similar to those used in previous work $(1,2,3)$, but without vacuum. It utilizes the effect of total reflexion at the sample support for background reduction. We use a fine structure $X$-ray tube with molybdenum anode together with a power supply DEBYEFLEX 2002 from SEIFERT, goniometer with a holder for the sample support (SEIFERT), and slits, diaphragms and filters for collimation and background reduction in the geometric arrangement shown in figure 1.

The incident X-ray beam strikes the surface of the sample support, an optical flat made of SUPRASIL quartz glass with dimensions $50 \times 30 \times 15 \mathrm{~mm}$, at an angle of about 6 minutes of arc. The sample is deposited in the center of the support surface. Immediately above the sample (about $1 \mathrm{~mm}$ ) a diaphragm

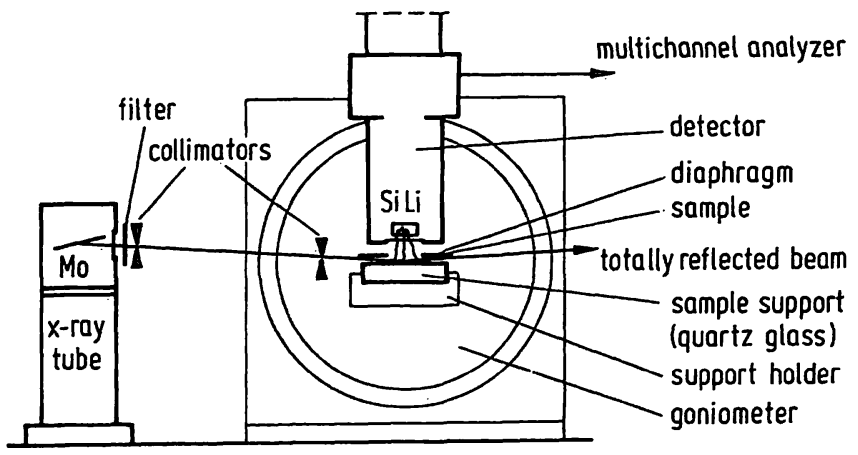

Fig. 1. Experimental setup for X-ray fluorescence analysis with totally reflecting sample support.

with an inner diameter of $8 \mathrm{~mm}$ is attached to the sample holder. The fluorescence radiation is analyzed by a $\mathrm{Si}(\mathrm{Li})$ detector located at $10 \mathrm{~mm}$ from the sample and connected to standard electronics. A typical serum spectrum is shown in figure 2.

In contrast to the conventional XRF technique (4) the used method needs practically no sample preparation. $10 \mu \mathrm{l}$ of serum were pipetted onto the cleaned surface of the glass block and allowed to dry in the air.

The main application of the X-ray fluorescence analysis with totally reflecting sample support is the determination of trace elements in aqueous solutions or organic extracts with a low content of dissolved matter. In these cases the sample residue on the support after drying is in the range of 0.01 of the original volume and only a few $\mu \mathrm{m}$ thick. Human blood serum, however, 


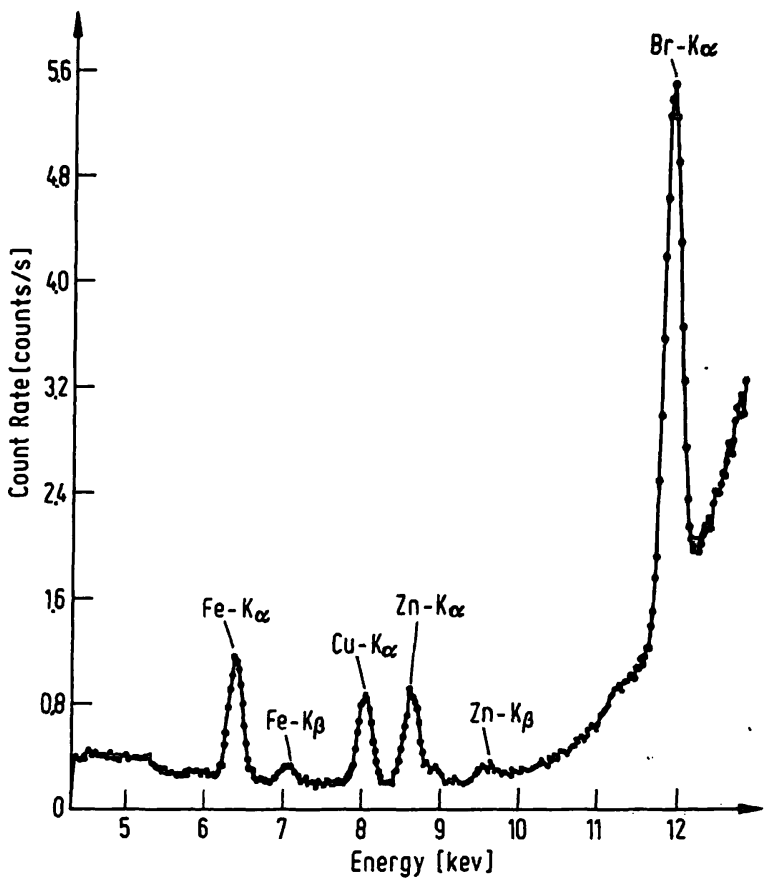

Fig. 2. X-ray fluorescence spectrum of human blood serum, containing $35.3 \mathrm{mmol} / 1$ iron, $13.2 \mathrm{mmol} / 1$ copper, $13.3 \mathrm{mmol} / \mathrm{l}$ zinc, $42.6 \mathrm{mmol} / 1$ bromine.

$\infty$ ntains about $100 \mathrm{~g} / \mathrm{l}$ of proteins, lipids and minerals leading to films of $20-50 \mu \mathrm{m}$ thickness. Taking into account the simplicity of the drying procedure, it cannot be excluded that there were films with humps and marginal ridges up to $200 \mu \mathrm{m}$ (freeze-drying, e. g., gave much better films). Due to the very small angle of the incident beam we have to face paths of the exciting $\mathrm{X}$-rays up to the $\mathrm{mm}$ range in the dried serum which may cause shading effects. It may also happen that certain parts of the sample are not hit by the strongly collimated beam. It is therefore necessary to determine to what extent the sample is actually penetrated by the incident radiation. We found that in this technique, as in conventional XRF, the height of the Compton peak is proportional to the sample mass seen by the incident $X$-rays. Hence, the ratio of metal peak to Compton height is proportional to the concentration of metal atoms in the dry substance of the serum and this ratio is independent of film shape and possibly imperfect pipetting. Since the metal concentration of the whole serum is usually requested, the metal peak to Compton height ratio was multiplied by the dry fraction. The dry fraction can be easily determined by weighing a small volume of serum $(0.5 \mathrm{ml})$ before and after drying to an accuracy better than 0.5 percent. So all concentrations given in this paper apply to the whole sera.

The calibration was done with commercial control sera which are generally used in medical laboratories for accuracy control. Their iron and copper concentrations are not known to the accuracy desired for our purpose. Nevertheless, in order to avoid systematic errors we did not try to prepare standards by simulating a serum matrix and adding known amounts of metal salts.

\section{Results}

The results of the measurements are given in table 1 and 2. Plots of the calibration of the $\mathrm{X}$-ray spectrometer are shown in Figures 3 and 4, where the solid lines were calculated by least squares fitting. The blank values at $0 \mathrm{mmol} / \mathrm{l}$ were caused by the apparatus and could be experimentally confirmed by measuring a metal-free aqueous sodium diethyldithiocarbamate solution with a content of $83 \mathrm{~g} / \mathrm{l}$.
Tab. 1. Results of measurements of copper in serum.

\begin{tabular}{|c|c|c|c|}
\hline Serum name & $\begin{array}{l}\text { Mean } \\
\left.\text { value }^{\mathrm{f}}\right) \\
(\mathrm{mmol} / \mathrm{1} \\
\mathrm{Cu})\end{array}$ & $\begin{array}{l}\text { Acceptable } \\
\left.\left.\text { range }^{\mathrm{f}}\right)^{\mathrm{g}}\right) \\
(\mathrm{mmol} / 1 \\
\mathrm{Cu})\end{array}$ & $\begin{array}{l}\text { Measured } \\
\text { value } \\
(\mathrm{mmol} / 1 \\
\left.\left.\frac{\mathrm{Cu}}{\mathrm{x}} \pm \mathrm{s}^{\mathrm{k}}\right)\right)\end{array}$ \\
\hline Individual serum $\mathbf{e}^{\mathbf{e}}$ ) & 12.6 & - & $13.2 \pm 0.3$ \\
\hline Monitrol $\mathrm{II}^{\mathrm{c}}$ ) & 16.4 & $14.6-18.1$ & $15.3 \pm 0.3$ \\
\hline Precilipa ) & 18.6 & $15.6-21.6$ & $17.6 \pm 0.2$ \\
\hline Kontrollogen- $\mathrm{L}^{\mathrm{b}}$ ) & 19.7 & $17.5-21.9$ & $18.9 \pm 0.5$ \\
\hline Monitrol $I^{c}$ ) & 20.5 & $17.9-23.0$ & $22.3 \pm 0.2$ \\
\hline Monitrol X $\mathrm{X}^{\mathrm{d}}$ ) & 23.0 & $20.1-25.8$ & $23.3 \pm 0.5$ \\
\hline Precinorm- $\mathrm{S}^{\mathrm{a}}$ ) & 24.7 & $20.9-28.5$ & $25.2 \pm 0.8$ \\
\hline Fluinorm-Pb) & 25.5 & $22.7-28.3$ & $24.2 \pm 0.5$ \\
\hline Fluinorm: $\mathrm{N}^{\mathrm{b}}$ ) & 32.3 & $28.3-36.2$ & $30.4 \pm 1.1$ \\
\hline Cation-Cal ${ }^{c}$ ) & 34.8 & - $\quad$. & $36.7 \pm 2.5$ \\
\hline Precipath-S $S^{a}$ ) & 78.8 & $71.0-86.7^{\circ}$ & $78.7 \pm 1.6$ \\
\hline "R1"h) & $\left.14.9^{i}\right)$ & $\left.12.7-17.8^{j}\right)$ & $13.8 \pm 0.3$ \\
\hline "(R2"h) & $\left.18.6^{i}\right)$ & $\left.15.3-22.8^{j}\right)$ & $16.7 \pm 0.3$ \\
\hline
\end{tabular}

a) Boehringer Mannheim GmbH

b) Behringwerke AG/Marburg-Lahn

c) DADE/Miami Fla. 33152, U.S.A.

d) Natural mixed serum

q One author's serum, analysed by clinical laboratory Dr. Kramcr/Geesthacht

f) Manufacturer's specification

g) Twice the standard deviation

h) Measurements of two unknown sera in the course of an intercomparison test (Sept. 1976, 226 laboratories)

j) Reference value

j) Acceptable range indicates here the required accuracy to stand the test

k) at least five determinations over a period of two weeks.

Tab. 2. Results of measurements of iron in serum.

\begin{tabular}{|c|c|c|c|}
\hline Serum name & $\begin{array}{l}\text { Mean } \\
\left.\text { value }^{\mathrm{f}}\right) \\
(\mathrm{mmol} / \mathrm{l} \\
\mathrm{Fe})\end{array}$ & $\begin{array}{l}\text { Acceptable } \\
\left.\left.\text { range }^{\text {f }}\right)^{\mathrm{g}}\right) \\
(\mathrm{mmol} / 1 \mathrm{Fe})\end{array}$ & $\begin{array}{l}\text { Measured } \\
\text { value } \\
(\mathrm{mmol} / \mathrm{l} \\
\frac{\mathrm{Fe}}{\left.\left.\overline{\mathrm{x}} \pm \mathrm{s}^{\mathrm{k}}\right)\right)}\end{array}$ \\
\hline Monitrol II') & 12.4 & $10.9-13.8$ & $13.6 \pm 0.5$ \\
\hline Kontrollogen $-L^{b}$ ) & 13.3 & $10.4-16.1$ & $14.9 \pm 1.1$ \\
\hline Monitrol $I^{\mathfrak{c}}$ ) & 15.8 & $13.4-18.8$ & $15.4 \pm 1.1$ \\
\hline Precinorm- $S^{a}$ ) & 18.1 & $15.4-20.8$ & $14.5 \pm 0.7$ \\
\hline Precilip $^{a}$ ) & 23.8 & $20.1-27.6$ & $25.6 \pm 0.5$ \\
\hline Fluinorm-N $\mathrm{N}^{\mathrm{b}}$ ) & 27.4 & $25.1-29.7$ & $24.2 \pm 0.5$ \\
\hline Fluinorm- $\mathbf{P}^{\mathbf{b}}$ ) & 30.1 & $27.8-32.4$ & $29.4 \pm 0.7$ \\
\hline Cation-Cal ${ }^{c}$ ) & 35.5 & - & $34.0 \pm 0.2$ \\
\hline "R1"h) & $\left.32.4^{i}\right)$ & $\left.28.8-36.7^{\mathrm{j}}\right)$ & $33.8 \pm 0.4$ \\
\hline "R2"h) & $\left.19.9^{i}\right)$ & $\left.17.7-22.2^{j}\right)$ & $18.8 \pm 1.3$ \\
\hline
\end{tabular}

a) - k) For footnotes see tab. 1. 


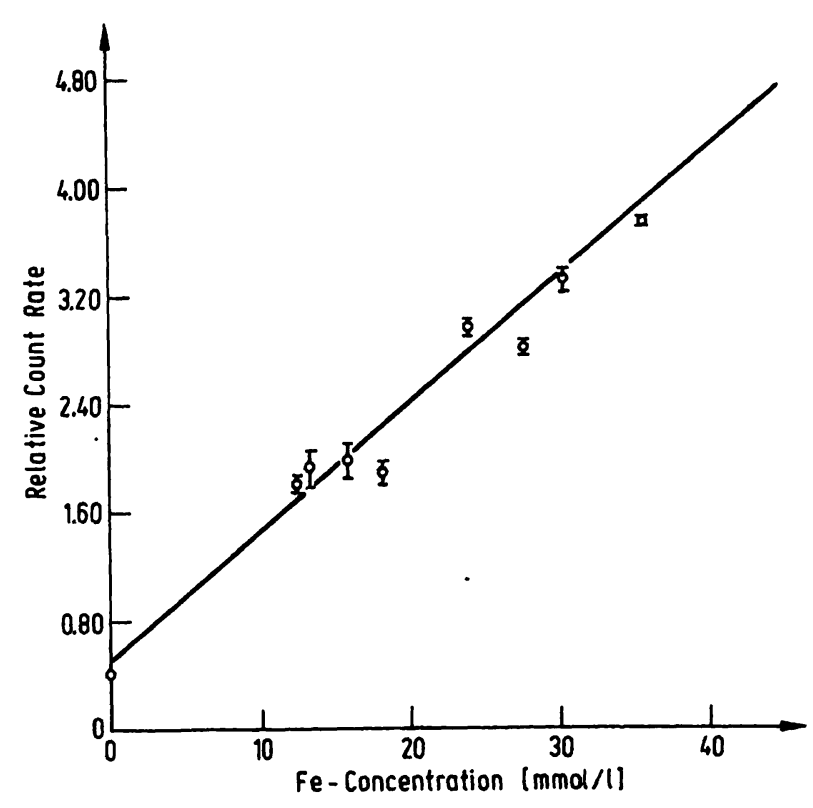

Fig. 3. Calibration line for iron of the X-ray spectrometer obtained with the aid of standard sera.

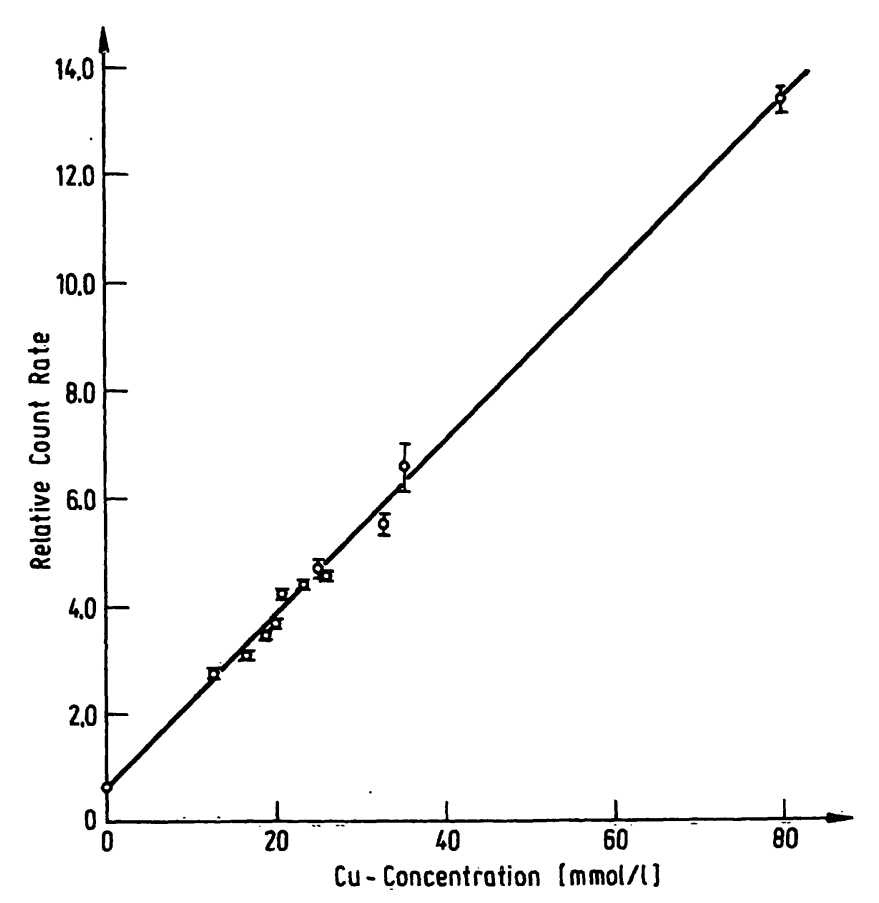

Fig. 4. Calibration line for copper of the X-ray spectrometer obtained with the aid of standard sera.

The reproducibility, i. e. the standard deviation of at least five samples of the same serum, over a period of about 2 weeks was about $3 \%$ for copper and $5 \%$ for iron using a measuring time of $1000 \mathrm{~s}$.

The accuracy of a calibration with imperfect standards can be estimated by regression calculations. The resulting standard deviation $S$ of a measured concentration $\mathrm{c}$ was evaluated as follows (5):

$$
S^{2}=\frac{S Q R}{n-2} \cdot\left(\frac{\left(c-c_{m}\right)^{2}}{Q}+\frac{1}{n}+1\right)
$$

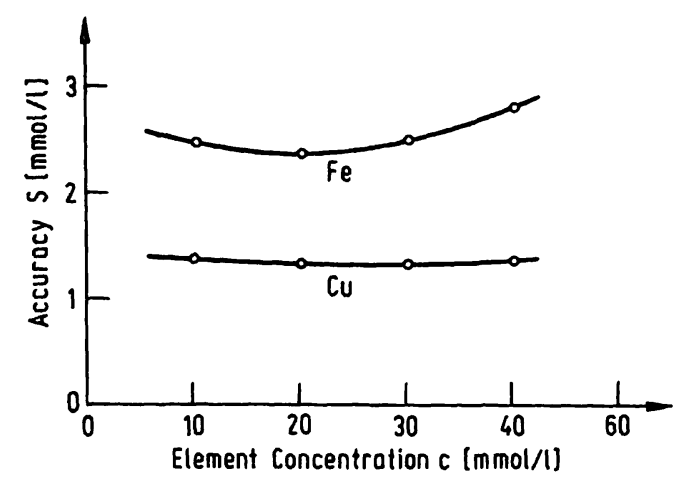

Fig. 5. Accuracy of the determination of iron and copper in blood serum based on the standards used in this work.

with

$\mathrm{SQR}=$ sum of the squared residuals of the standard concentrations $c_{i}$

$\mathrm{n} \quad=$ number of standards

$\varepsilon_{m} \quad=$ mean concentration of the standards

$Q \quad=\Sigma\left(c_{i}-c_{m}\right)^{2}$

The above defined standard deviation $\mathrm{S}$ for iron and copper with the set of standards used is plotted in figure 5.

The conventional criterion of statistical detectability, where the minimum peak area is three times the square root of the background counts under the peak, would give $0.9 \mathrm{mmol} / 1$ for iron and $0.6 \mathrm{mmol} / \mathrm{l}$ for copper in $1000 \mathrm{~s}$.

\section{Conclusion}

The measurements were performed with a quite preliminary setup not optimized with respect to some important parameters, e. g., background, collimation and adjusting possibilities. An apparatus with automatic sample changer and mechanical improvements for routine applications is under construction (6).

In the X-ray spectra (fig. 2 ) of all analyzed sera a zinc peak was also present with an intensity comparable to that of copper. In some cases bromine, mercury and lead were conspicuous. These elements can be determined with practically the same precision and sensitivity as iron and copper in one measurement. It should be pointed out that the essential biological metal zinc is not yet routinely determined in blood serum in the clinical laboratory practice, although there is growing evidence that zinc, too, can be very important in the early diagnosis of certain diseases including cancers. (K.-D. Voigt, personal communication). 


\section{Acknowledgements}

The authors wish to thank Dr. Kramer and Mr. vom Baur from the Laboratorium Dr. Kramer at Geesthacht for their kind support and control measurements. They are further indebted

\section{References}

1. Yoneda, Y. \& Horiuchi, T. (1971), Rev. Sci. Instr., 42, $1069-1070$

2. Aiginger, H. \& Wobrauschek, P. (1974), Nucl. Instr. Meth., $114,157-158$.

3. Wobrauschek, P. \& Aiginger, H. (1975), Anal. Chem., 47, 852-855. to Prof. K.-D. Voigt of the Universitätsklinik Hamburg-Eppendorf for useful remarks. The authors are also grateful to Behringwerke AG and Boehringer/Mannheim for kindly providing several control sera.
4. Flint, R. W., Lawson, C. D. \& Standil, S. (1975), J. Lab. Clin. Med., 85, 155-160.

5. Sachs, L. (1969), Statistische Auswertungsmethoden, 2nd. ed., Springer-Verlag.

6. Marten, R., Rosomm, H. \& Schwenke, H. Dtsch. Bundes-Pat. pending, P 2632001.4

J. Knoth

c/o Gesellschaft für Kernenergieverwertung

in Schiffbau und Schiffahrt mbH.

Postfach 160

2054 Geesthacht-Tesperhude 